\title{
Thrombocyte Aggregative Activity of Irshire Breed Calves of Milk Nutrition
}

\author{
Medvedev Ilya Nikolayevich (Corresponding author), \\ Kursk Institute of Social Education (branch) of Russian State Social Education, \\ 305029, K.Marx st., Kursk, Russia \\ Oshurkova Julija Leonidovna \\ Federal State Budgetary Educational Institution of Higher Education "Vologda State Dairy \\ Farming Academy by N.V. Vereshchagin", \\ 160555, Schmidt st., Vologda, Russia
}

Received: October 8, 2016

doi:10.5296/jas.v4i4.10236
Accepted: October 21, 2016 Published: October 31, 2016

URL: http://dx.doi.org/10.5296/jas.v4i4.10236

\begin{abstract}
Evaluation of blood indices and especially hemostasis elements of productive cattle has great practical meaning for biology. They are closely connected with their somatic characteristics and functioning processes of the whole organism. Clarification of their values allows to work out age-specific norms of given indices and to define clearly the beginning of hemostasiopathy coming. High productivity of Irshire cattle and great meaning of thrombocyte activity of its cubs enduced to make evaluation of blood platelets aggregation. The aim of the work: to define peculiarities of thrombocyte activity of Irshire breed healthy calves during milk nutrition phase. There was fulfilled the investigation of 65 milk nutrition calves of Irshire breed with the usage of hematological research methods. The most active thrombocyte aggregation was noted for adenosine diphosfate being maximum to the end of investigation. Collagenous and rhystomitzine aggregation had less intensity and similar direction what indirectly pointed at not high collagen availability and not large Willybrand's factor concentration in it. Deaggregative thrombocyte capabilities in response to all the used inductors in case of Irshire calves of milk nutrition had tendency to growth. Not high thrombocyte activity provides cattle of this breed during growth and development optimal conditions for blood supply of growing and ripening organs.
\end{abstract}

Keywords: thrombocytes, calves, milk nutrition, Irshire breed.

\section{Introduction}

Processes of growth and development are closely connected with the dynamics of systems 
regulating and integrating living organisms among which we find blood (Glagoleva, 2015). From the physiological point of view its extremely important biological subsystem providing, from one hand, preservation of its liquid state, and from the other hand, prevention and reduction of bleeding is hemostasis (Glagoleva, 2016; Levi, 2005).

Hemostasis functioning is provided by a whole range of different components rather significant of which are thrombocytes (Shitikova, 2008) also seriously influencing hemocoagulation activity (Zavalishina, 2011 a; Kutafina, 2015). It was noted that thrombocyte functional perfection really influence tissue blood supply efficiency and organism's stability to different pathological states (Wagner, Eckman and Wick, 2006; White and Rompietti, 2007).

We consider that great practical significance for biology has the evaluation of blood indices and especially hemostasis elements of productive cattle. These indices are surely closely connected with their somatic characteristics (Korepanova, Starostina and Batanov, 2015) and the whole organism's functioning (Zavalishina, 2011 b). It dictates the necessity of working out of age-specific norms of the taken indices (Zavalishina, 2013; Zavalishina, 2015) for early detection of the beginning of hemostasiopathy coming in case of some states (Shitikova, 2008). These investigations have especially great significance for highly productive breeds of agricultural cattle (Zavalishina, 2016).

Because of high productivity of Irshire cattle and importance for optimum of its physiological status and its thrombocyte activity's productivity it was decided to evaluate blood platelets activity of its cubs.

\section{Purpose of the study}

To define peculiarities of thrombocyte activity of Irshire breed healthy calves during milk nutrition phase.

\section{Methods}

Investigation was fulfilled with the help of 65 Irshire breed healthy calves of milk nutrition from pedigree plant "Majsky", Vologda district, Vologda region. The calves were examined 5 times: on the 11-th day, on the 15-th day, on the 20-th day,on the 25-th day and on the 30-th day of life.

For the investigation of thrombocyte parameters all the calves were taken blood from jugular vein in the morning. It was taken into plastic test tube containing 3,8\% solution of natrium nitrate inratio of blood and natrium nitrate volumes $-9: 1$.

The number of thrombocytes, their average volume and thrombocryn (index characterizing percentage of thrombocyte mass in blood volume) were defined with the help of electronic-automatic method by hematological analizator BC-3000 PLUS.

Aggregative thrombocyte activity was found with the help of quantity method by photoelectrocolorimeter KFK-2 with the usage as aggregation inductors of ADF, collagen and rhystomitzin in standard concentrations. Thrombocyte aggregation was evaluated according to summarizing index of thrombocyte aggregation (SITA), aggregation speed (AS) and index of thrombocyte deaggregation (ITD). 


\section{$\triangle$ Macrothink}

Journal of Agricultural Studies ISSN 2166-0379 2016, Vol. 4, No. 4

Results received during investigation were processed with the help of the programme Microsoft Excel and presented as $\mathrm{M} \pm \mathrm{m}$. Age-specific dynamics of the taken indices was evaluated with the usage of Student's t-criteria.

\section{Results}

Overall thrombocyte indices of investigated calves (the number of thrombocytes, their average volume and thrombocryt) were within norms showing no dynamics during investigation (table 1).

Table 1. Overall thrombocyte blood characteristics of milk nutrition calves of the Irshire breed

\begin{tabular}{|l|c|c|c|c|c|}
\hline \multirow{2}{*}{ Parameters } & \multicolumn{5}{|c|}{ Calves' age, $\mathbf{n = 6 5 ,} \mathbf{M} \pm \mathbf{m}$} \\
\cline { 2 - 6 } & $11^{\text {th }}$ day & $15^{\text {th }}$ day & $20^{\text {th }}$ day & $25^{\text {th }}$ day & $30^{\text {th }}$ day \\
\hline $\begin{array}{l}\text { Thrombocyte } \\
\text { quantity, } \\
\text { thousand/mcl }\end{array}$ & $385,9 \pm 9,62$ & $345,8 \pm 8,33$ & $336,1 \pm 5,81$ & $328,6 \pm 7,22$ & $314,7 \pm 8,01$ \\
\hline $\begin{array}{l}\text { Average } \\
\text { thrombocyte } \\
\text { volume,fl }\end{array}$ & $7,3 \pm 0,18$ & $7,3 \pm 0,23$ & $7,2 \pm 0,17$ & $7,2 \pm 0,27$ & $7,3 \pm 0,19$ \\
\hline \begin{tabular}{l} 
Thrombocryt, $\%$ \\
\hline
\end{tabular} & $0,27 \pm 0,05$ & $0,27 \pm 0,08$ & $0,27 \pm 0,04$ & $0,27 \pm 0,07$ & $0,27 \pm 0,06$ \\
\hline
\end{tabular}

Note: reliability of dynamics' indices wasn't found.

As a result of aggregative thrombocyte activity investigation of milk nutrition calves of Irshire breed there was found the tendency to its increasing (table 2).

Table 2. Aggregative thrombocyte activity of milk nutrition calves of Irshire breed

\begin{tabular}{|c|c|c|c|c|c|}
\hline \multirow[t]{2}{*}{ Parameters } & \multicolumn{5}{|c|}{ Calves' age, $n=65, M \pm m$} \\
\hline & $11^{\text {th }}$ day & $15^{\text {th }}$ day & $20^{\text {th }}$ day & $25^{\text {th }}$ day & $30^{\text {th }}$ day \\
\hline \multicolumn{6}{|c|}{ aggregation inductor ADF } \\
\hline SITA, $\%$ & $14,80 \pm 1,45$ & $16,02 \pm 2,02$ & $17,00 \pm 3,08$ & $17,20 \pm 2,62$ & $18,00 \pm 2,27$ \\
\hline $\mathrm{AS}, \min$ & $0,021 \pm 0,007$ & $0,022 \pm 0,009$ & $0,024 \pm 0,007$ & $0,025 \pm 0,008$ & $0,026 \pm 0,005$ \\
\hline ITD, $\%$ & $10,10 \pm 0,68$ & $9,95 \pm 0,73$ & $10,00 \pm 0,63$ & $10,05 \pm 0,80$ & $10,25 \pm 0,75$ \\
\hline \multicolumn{6}{|c|}{ aggregation inductor collagen } \\
\hline SITA, $\%$ & $6,17 \pm 0,53$ & $6,32 \pm 0,61$ & $6,65 \pm 0,50$ & $6,85 \pm 0,63$ & $7,01 \pm 0,49$ \\
\hline AS,min & $0,0052 \pm 0,005$ & $0,0054 \pm 0,003$ & $0,0055 \pm 0,006$ & $0,0058 \pm 0,004$ & $0,0061 \pm 0,006$ \\
\hline ITD, $\%$ & $2,43 \pm 0,23$ & $2,48 \pm 0,25$ & $2,47 \pm 0,28$ & $2,48 \pm 0,18$ & $2,50 \pm 0,22$ \\
\hline \multicolumn{6}{|c|}{ aggregation inductor rhystomitzin } \\
\hline SITA, $\%$ & $7,53 \pm 0,19$ & $7,65 \pm 0,24$ & $7,70 \pm 0,29$ & $7,73 \pm 0,33$ & $7,80 \pm 0,31$ \\
\hline AS,min & $0,0061 \pm 0,005$ & $0,0059 \pm 0,008$ & $0,0060 \pm 0,007$ & $0,0064 \pm 0,005$ & $0,067 \pm 0,007$ \\
\hline ITD, $\%$ & $2,07 \pm 0,06$ & $2,10 \pm 0,09$ & $2,13 \pm 0,12$ & $2,11 \pm 0,08$ & $2,15 \pm 0,10$ \\
\hline
\end{tabular}

Note: reliability of dynamics' indices wasn't found. 
The largest thrombocyte response was noted on ADF - its SITA had a tendency to increasing, reaching $18,00 \pm 2,27 \%$. In response to collagen SITA of calves during milk nutrition also gradually increased to $7,01 \pm 0,49 \%$. Thrombocyte aggregation activity under rhystomitzin influence in case of examined calves also had a tendency to increasing - SITA to $7,80 \pm 0,31 \%$.

Aggregation formation speed of Irshire breed calves during milk nutrition phase in response to $\mathrm{ADF}$ had a tendency to increasing to $0,026 \pm 0,005 \mathrm{~min}$. Similar dynamics existed for thrombocyte AS under the influence of collagen and rhystomitzin reaching in case of calves to the end of investigation $0,0061 \pm 0,006 \mathrm{~min}$, correspondingly.

The index value of thrombocyte deaggregation showing stability of appearing aggregants was the least one on rhystomitzin $(2,15 \pm 0,10 \%)$. Aggregates formed under the influence of ADF and collagen during milk nutrition turned out to be less stable: ITD in relation to both inductors gradually increased,reaching with collagen $2,50 \pm 0,22 \%$, and with ADF $10,25 \pm 0,75 \%$.

\section{Discussion}

Existing nowadays high level of knowledge about hemostasis physiology allows to consider this system to be of special significance in supporting organism's functional optimum (Wagner, Eckman and Wick, 2006). Hemostasis activity isn't similar in different parts of bloodstream (Zavalishina, 2011 a). In functionally active at the given moment organs we can establish the definite hemostasis level differing from the general bloodstream what is connected with hemostasis system mjsaisity in different parts of blood stream (Lazareva, Mamotrueva and Lomakin, 2005).

Last years investigations significantly widened our ideas about factors influencing thrombocyte aggregation and also blood preservation in liquid state. These processes are well examined at many states of people and animals (Shitikova, 2008). At the same time, a great number of aspects of thrombocyte hemostasis component of cattle in different ages and in many conditions of environment stay examined rather poorly (Lazareva, Mamotrueva and Lomakin, 2005). Their breed peculiarities are left unfound, for example, as far as Irshire breed is concerned, including during the most potentially productively-significant period - of calves in milk nutrition phase.

It is agreed that during the whole milk nutrition phase in calves' organisms happen anabolic physiologically necessary processes, and it causes definite shifts in the work of all the organs and organism's systems (Glagoleva,2016). Exactly at this period all the tissues are mostly influenced by unfavourable factors of the environment and need maximum blood supply and its good liquid features (Zavalishina,2015).

Fulfilled investigations on Irshire breed calves of milk nutrition showed that thrombocyte quantity and their average volume do not exceed common normative meanings (Shitikova,2008). At the same time their aggregative thrombocyte activity during milk nutrition phase gradually increases. Most actively thrombocytes react on ADF action. With age increase SITA with this inductor also increased. At the same time in response to collagen 
and rhystomitzin SITA reaches less congruent meanings. It indirectly points at not high level of collagen availability during milk nutrition phase at not high content of Willybrand's factor in their blood (Zavalishina,2016). Inclination to increase of Irshire calves during milk nutrition phase with all the inductors pointed at number increase of corresponding receptors on thrombocyte membranes. Evidence of deaggregative thrombocyte capacities of examined calves during milk nutrition phase in response to all the agonists increased in similar degree. Given phenomenon can also be explained by receptor restructuring of thrombocyte membranes and dynamics in thrombocytes of their activation mechanisms (synthesis of thromboxan, phosphatidic acid and thrombocyte activation factor).

Evaluating received data from examined animals we can conclude that during milk nutrition calves of Irshire breed experience increase of adhesively-aggregative thrombocyte activity, mostly evident to its end. Taking into consideration that calves' growth and development last rather long simultaneously, it becomes clear that both these processes influence adhesively-aggregative thrombocyte activity. Existing brief literature data about the fact that calves while growing have either decrease of thrombocyte aggregative features (Glagoleva,2015) or their increase, or their stability takes place (Zavalishina, 2016), can be explained by breed heterogeneity of examined animal groups taken into these investigations or fulfilling these investigations in incomparable environmental conditions (Zavalishina, 2011 a).

\section{Conclusion}

Calves of Irshire breed during milk nutrition phase are noted to have physiologically proved dynamics of thrombocyte hemostasis indices. Not high thrombocyte activity provides animals of this breed during growth and development with optimal conditions for bloodsupply of growing and ripening organs.

\section{References}

Glagoleva, T. I. (2016) Ontogenetic dynamics of cattle's main hematological indices. Veterinary science, zooculture and biotechnology, 5, 66-69.

Glagoleva, T.I. (2015) Vascular control over aggregative features of regular blood elements in case of milk nutrition calves. Research records of Kazan State academy of veterinary medicine named after N.E. Bauman, 222(2), 58-62.

Zavalishina, S. Y. (2011 a) Coagulatory activity of calves' blood plasma at plant nutrition. Veterinary science, 4, 48-49.

Zavalishina, S. Y. (2011 b) Hemostasis system functional state of new-born calves. Veterinary science, 6, 42-45.

Zavalishina, S.Yu. (2013) Vascular hemostasis of new-born calves with iron deficiency who were given ferroglucyn. Zooculture, 8, 24-26.

Zavalishina, S. Y. (2015) Vascular-thrombocyte interactions of incalvers. Fundamental researches, 2(part 2), 267-271. 


\section{Macrothink}

Journal of Agricultural Studies

ISSN 2166-0379

2016, Vol. 4, No. 4

Zavalishina, S. Y. (2016) Vascular hemostasis physiological peculiarities of cows at the beginning of lactation. Veterinary science, zooculture and biotechnology, 5, 50-54.

Korepanova, L.V., Starostina, O. S., \& Batanov, S. D. (2015) Blood as the index of interior features of crossbreed animals. Zooculture, 10, 26-28.

Kutafina, N. V. (2015) Thrombocyte mechanisms on the background of cattle growth processes. Veterinary science, zooculture and biotechnology, 8, 37-42.

Lazareva, E. N., Mamotrueva, M. A., \& Lomakin, N. N. (2005) Modern view on thrombocyte morphofunctional peculiarities. Natural sciences, 3, 36-42.

Shitikova, A. S. (2008) Inborn and acquired kinds of thrombocitopathy. St.Petersburg: Informative-publishing centre of Military-medicinal academy, 384.

Levi, M. (2005) Platelets. Crit. Care. Med, 33, 523-525.

Wagner, M. C., Eckman, J. R., \& Wick, T. M. (2006) Histamine increases sickle erythrocyte adherence to endothelium. Brit. J. Haematol, 4, 512-522.

White, G. C., \& Rompietti, R. (2007) Platelet secretion: indiscriminately spewed forth or highly orchestrated? J. Thromb. Haemost, 5, 2009-2016.

\section{Copyright Disclaimer}

Copyright for this article is retained by the author(s), with first publication rights granted to the journal.

This is an open-access article distributed under the terms and conditions of the Creative Commons Attribution license (http://creativecommons.org/licenses/by/3.0/). 